\title{
Artemisia Plants: A Deadly Weapon Against Tropical Diseases
}

\section{Pierre Lutgen}

IFBV-BELHERB, Luxembourg, Jérôme Munyangi, Maniema, RDCongo, Lucile Cornet-Vernet, M4L France

Since 9 years the association IFBV-BELHERB from Luxembourg has established a working relationship with African and South American universities, in close cooperation with other European research institutions. Several of these partners have run clinical trials with Artemisia annua tea. In all these trials a therapeutical effect of $95 \%$ or higher was confirmed by the use over 7 days of whole leaf infusion [1-4] capsules or tablets. One of the surprising effects noticed in these trials was that that the artemisinin content had very little impact on the results. This lead us to make an analysis as complete as possible of all the constituents, organic and inorganic, in a large series of Artemisia annua samples from different origins [5]. The effect of polysaccharides, amino acids, polyunsaturated fatty acids, pentacyclic triterpenes, cumarins, phytosterols and saponins has been neglected in the past [6]. Several papers have shown that A. annua ingested as powdered leaves or in conjunction with fatty food significantly increases the artemisinin concentration in the blood and even overcomes resistance to artemisinin [7]. It is well documented in the literature that $A$. afra or sieberi which contain little or no artemisinin are extensively used as antimalarials. They contain at least 5 molecules of the same antimalarial efficacy as artemisinin. Recent research from the Al Quds University has shown that aqueous infusions of several Artemisia species strongly inhibit beta-hematin, like chloroquine did [8]. But the most important finding in several of the clinical trials, especially in Kenya and Uganda, was that people who drink one or two cups of Artemisia annua tea per week become immune against malaria [9]. At Lubumbashi, RDCongo Dr C Kansango Tchandema has shown in 2014 that Artemisia annua and Artemisia afra raised $\mathrm{CD}^{4+}$ [2]. Anti-HIV properties of Artemisia afra have been documented by a team at the University of Leiden [10]. Strong prophylactic results have been obtained with ARTAVOL, a mixture of herbs developed Dr Patrick Ogwang at the Ministry of Health. The produce does not contain Artemisia without artemisinin. In fact the antimalarial properties of Artemisia plants other than Artemisia апnиa are no surprise. The Chinese favoured Artemisia apiacea and the French in Algeria during 100 years protected their soldiers against malaria with Artemisia absinthium.

In 2015 a team of medical doctors in RD Congo, Jerome Munyangi and Michel Idumbo, have run randomized clinical trials on a large scale in the Maniema province with the participation of some 1000 malaria infected patients. The trials were run in conformity with the WHO procedures and compared Artemisia annua and Artemisia afra with ACTs (Coartem and ASAQ). For all the parameters tested herbal treatment was significantly better than ACTs: faster clearance for fever and parasitemia, absence of parasites and gametocytes as confirmed by PCR on day 28 for $99.5 \%$ of the Artemisia treatments and $79.5 \%$ only for the ACT treatments. A total absence of side effects was evident for the treatments with the plants, but for the 498 patients treated with ACTs, 210 suffered from diarrhea, and/or nausea, pruritus, hypoglycemia etc. The efficiency was equivalent for Artemisia annua and Artemisia afra [2]. More important even is the observation for the total absence of gametocytes after 7 days treatment with the herb. A tremendous hope found for malaria eradication. The results have been communicated to the local health authorities, and to the Ministries of Health and Research in the RDCongo who were supportive of these trials. The draft of a paper is almost ready and will be submitted to a peer reviewed scientific journal.

\section{Publication History:}

Received: August 25, 2016

Accepted: October 06, 2016

Published: October 08, 2016

\section{Keywords:}

Artemisia, Tropical diseases, Clinical trials , Tuberculosis infection, Malaria

In parallel with the clinical trials against malaria, (see Breaking News Jan. 5 on www.malariaworld.org) the same team has completed another large scale randomized, double blind trial against schistosomiasis, Artemisia vs Praziquantel. The results confirm previous anecdotic results from several countries in Africa. Both arms in this trial had 400 infected patients. The treatment efficiency was $97 \%$ in the Artemisia arm and $71 \%$ in the Praziquantel arm. No side effects were noticed in the Artemisia treatment. Praziquantel caused vomiting in $26.5 \%$ of the patients, abdominal pain in $18.5 \%$, cephalalgy in $15.5 \%$. Very impressive is the fact that the Artemisia treatment led to an unexpected almost complete absence of eggs in feces after 2 months. Schistosomiasis kills 150000 Africans per year and more than 70000000 are infected. A neglected disease in poor populations, where the only existence is drug, Praziquantel, loses efficiency year after year.

In 2016 clinical trials have been run against Tuberculosis and Buruli ulcer with Artemisia annua and Artemisia afra. Screening trials in 2015 had been promising and these recent large scale, randomized, double blind have resulted in an obvious therapeutic effect of these plants against Mycobacteria, not only tuberculosis but also Buruli ulcer. After three weeks of treatment the Ziehl stain assay is negative for alcohol-resistant bacteria. They will be published in the scientific literature. Most of us ignore that on Nov 3, 2015 a Convention was signed in Bali declaring the fight against the looming TB-Diabetes coepidemic, one of the greatest global health challenges. An estimated two billion people, or one third of all people worldwide, live with a tuberculosis (TB) infection, of whom 9.6 million people develop active TB disease annually. TB is the leading cause of death worldwide due to a single infectious pathogen, responsible for 1.5 million human deaths in 2014, and 95 percent of human TB deaths occur in low- and middle-income countries. Diabetes mellitus is escalating worldwide. Clinical assays are planned to be run in the Katanga province of RDCongo with Artemisia plants against diabetes.

"Corresponding Author: Dr. Pierre Lutgen, IFBV-BELHERB, Luxembourg, Jérôme Munyangi, Maniema, RDCongo, Lucile Cornet-Vernet, M4L France, E-mail: lutgenp@gms.lu

Citation: Lutgen P (2016) Artemisia Plants: A Deadly Weapon Against Tropical Diseases. Int J Clin Res Trials 1: 108. doi: https://doi.org/10.15344/2456 8007/2016/108

Copyright: (C) 2016 Lutgen. This is an open-access article distributed under the terms of the Creative Commons Attribution License, which permits unrestricted use, distribution, and reproduction in any medium, provided the original author and source are credited. 
Citation: Lutgen P (2016) Artemisia Plants: A Deadly Weapon Against Tropical Diseases. Int J Clin Res Trials 1: 108. doi: https://doi.org/10.15344/2456$8007 / 2016 / 108$

All these trials are run in compliance with the WHO protocol, full approval of the health authorities of the country and the province and encouragements of WHO-Afro.

\section{Competing Interests}

The author declares that he has no competing interests.

\section{References}

1. Chougouo Kengne RD, Kouamouo J, Moyou Somo R, Penge On Okoko, et al. (2009) Comparative Study of the Quality and Efficiency of Artemisinin Drug Based and Artemisia annua grown in Cameroun, MIM conference, Nairobi, Kenya.

2. Kansango Tchandema C, Lutgen P (2016) In Vivo Trial on the Therapeutic Effects of Encapsulated Artemisia annua and Artemisia afra. Global J Res Ana 5: 228-234.

3. Gebeyaw T, Vigzaw 1, Tegbar V (2010) Use of the Plant Artemisia annua as Natural Anti-Malarial Herb in Arbaminch Town. Ethiop J Health Biomed Sc 2: 75-81

4. Zime-Diawara H, Ganfon H, Gbaguidi F, Yemoa A (2015) The antimalarial action of aqueous and hydro alcoholic extracts of Artemisia annua L. cultivated in Benin. J Chem Pharma Res 7: 817-823.

5. Chougouo Kengne RD (2010) Rapport de Stage. Mise au Point et Validation des Procédures analytiques pour la Détermination de certains Composés de la Plante Artemisia annua, Université des Montagnes, Cameroon, Laboratoire National de la Santé, Luxembourg.

6. Onimus M, Carteron S, Lutgen P (2013) The Surprising Efficiency of Artemisia annua Powder Capsules. Med Aromat Plants 2: 125

7. Elfawal M, Towler M, Reich NG, Weathers P, Rich S (2014) Dried whole-plant Artemisia annua slows evolution of malaria drug resistance and overcomes resistance to artemisinin.

8. Akkawi M, Suhair J, Ogwang PE, Lutgen P (2014) Investigations of Artemisia annua and Artemisia sieberi water extracts. Medic Aromatic Plants 3: 21670412.

9. Ogwang PE, Ogwal JO. Kasasa S. Deogratius O, Obua C (2012) Artemisia annua L. Infusion consumed once a Week reduces Risk of multiple Episodes of Malaria: A randomised tTrial in an Ugandan Community. Trop J Pharm res 13: 445-453.

10. Van der Kooy F (2014) Artemisia annua and its Anti-HIV Activity. In Aftab T, et al. (eds.), Artemisia Ann Pharmacol Biotech Springer-Verlag Berlin Heidelberg. 